Denysenko K. V.,

$\mathrm{PhD}$ in Public Administration, Associate Professor of the Department of Theory and History of State and Law, Constitutional Law, Academy of the State Penitentiary Service, Chernihiv, Ukraine

\title{
PENSION PROVISION FOR PERSONS DISMISSED FROM MILITARY SERVICE: PROBLEM QUESTIONS AND PROSPECTS FOR IMPROVEMENT
}

The article generalizes the legal regulation of pension provision of the persons retired from military service and the persons who are equal to them. It is proved that at the present stage of state formation and Ukrainian society development, it is especially important for our state to provide rights and freedoms, to give social support, to create favorable social environment, social security of the citizens who ensure the defense of the country, protecting its sovereignty, independence and territorial integrity.

It is determined that the imperfection of current state social policy, as well as negative trends that characterize the retirement provision of the persons retired from military service in modern conditions, do not contribute to the solvency of this category of citizens. Pension system reforming is overwhelmingly characterized by social injustice, unsystematic legislative stories that leads to narrowing and limiting the amount of pension rights, the abolition of privileges, unjustified increase in the requirements for acquiring the right to appoint pensions, and so on. The aforementioned did not pass the number of pensioners from the number of servicemen.

The necessity of clarification of the legal regulation of previously assigned pensions to the persons retired from military service recalculation and firstly, the components of monetary provision reviewing from which the recalculation of pensions is carried out, by including sums of monthly additional types of monetary support (allowances, surcharges, increments), premiums, including one-time benefits paid when discharged from military service; and secondly, approaches to determining the amount of recalculation of previously assigned pension.

Key words: pension provision, pension system, persons retired from military service, normative and legal regulation, pensioners, pension reform, pension recalculation.

Target setting. The current stage of development of state formation and Ukrainian society takes place in the context of fighting with the aggressor-state in the East of Ukraine. Therefore at present, it is especially important for our state to ensure the rights and freedoms, to provide social support, to create a supportive social environment, social security of citizens, which ensure the country`s defense, protecting its sovereignty, independence and territorial integrity at the cost of one's own life. 
As the scientists emphasize, the guaranteed social security of the military personnel creates and ensures the prestige of military service and acquisition of the Armed Forces of Ukraine with professional, highly skilled personnel. The solution to this problem will depend on the success and the fate of military reform, the further development of the army, its combat capability and the implementation of tasks for the defense of the Homeland [1, c. 39].

In its turn, it puts forward special requirements for the level of social protection of pensioners from the number of former military personnel, the creation of appropriate conditions for the implementation of social rights and guarantees after the termination of military service, in particular, the normative-legal regulation of pension for this category of citizens. However, practice shows that the imperfection of the current state social policy, as well as the negative trends that characterize the pension of persons dismissed from military service in modern conditions, do not contribute to the solvency of this category of citizens.

Actual scientific researches and issues analysis. Theoretical, methodological and applied aspects of functioning of the domestic pension system were studied by such scientists as: Andriiv V., Buriachenko O., Vyshnovetska S., Mindova O., Mokhova Yu., Nadiienko O., Pylypenko P., Pysarenko N., Silchenko S., Syrota I., Stashhkiv B., Chichkan M., Khutorian N., Yurchenko Yu. and many others.

Conceptually significant contribution to solving actual and problematic issues concerning the improvement of the normativelegal regulation of social protection and pensions of persons dismissed from military service was conducted by Venediktov V., Klemparskyi M., Kolotik A., Kravchenko M., Melnyk K., Shumna L.

Without diminishing the importance and value of the scientific work of the aforementioned scientists, additional researches require problematic issues in the pension functioning of persons dismissed from military service through the prism of revision of existing appointment mechanisms, recount and payment of pensions for this category of citizens, in particular in the context of the reform of pension legislation. 
Purpose setting. Generalization of normative-legal regulation of pensions of persons dismissed from military service, including the isolation and analysis of modern problem issues and the formulation of concrete ways to improve this area.

Statement of basic materials of the research. The last decade is characterized by significant reforms in the area of pension provision. Theoretically, the conceptual framework for reforming the specified industry was aimed at modernization and the search for the optimal ways, mechanisms and methods of functioning of an effective national pension system, in particular, the visible effectiveness of reforms should contribute to the life support of citizens, improvement of living standards, the level and quality of social protection.

However, practice shows that pension reform in the overwhelming majority is characterized by social injustice, unsystematic legislative novels, which leads to restriction and limiting the amount of pension rights, the abolition of privileges, the unjustified increase of the requirements for acquiring the right to appoint pension provision, etc. The aforementioned did not pass the pensioners from the number of military personnel.

In the opinion of the prominent domestic specialist in the field of pension provision Stashkiva B., a pension to military personnel and those equated to them is a monthly cash payment, which is appointed and paid by the territorial authority of the Pension Fund of Ukraine in connection with the existence of superannuated pensions and disability or breadwinner's loss to a precisely defined circle of persons under the conditions and in the manner prescribed by a special law, in order to the increased amount compensation of previously received retentioned money [2, c. 256].

It should be noted that historically, in the pension legal relations, the persons dismissed from military service and those equated to them were considered to be a privileged category of citizens, which was due to the presence of the last ones the legally established preferences in the form of privileges, surcharges, increases and additional guarantees in comparison with general subjects of pensions.

Conditions, norms and procedure of pension provision of Ukrainian citizens from the number of persons who were in military service, service in the internal affairs bodies, the National Police, the 
Service of the Court Guard, the State Emergency Service, the State Service of Special Communications and Information Protection of Ukraine, the bodies and subdivisions of the Civil Protection, the Tax Police or the State Criminal-Executive Service of Ukraine, and some other persons are regulated by the Law of Ukraine "On Pension Provision of Persons Dismissed from Military Service and Some Other Persons". The legal grounds for the pension provision of persons dismissed from military service are the following legal facts: the availability of legally established duration of service years, disability, breadwinner's loss, and in some cases the reaching a certain age and the avaliability of an insurance period [3].

It should be noted that more than sixty changes and additions were made to the Law of Ukraine "On Pension Provision of Persons Dismissed from Military Service and Some Other Persons", the overwhelming majority of which are aimed at increasing the superannuated pensions, in addition some of its provisions were declared unconstitutional. The mentioned leads to a rethinking of legislative short novels and pension realities, both for military personnel and for persons dismissed from military service.

For example, for the pension reform of 2011, superannuation pensions for officers, warrant officers and midshipmen, military personnel of the overhead service and service under the contract, other persons specified in clauses "b" - "d" of Article 1-2 of the Law "On Pension Provision of Persons Dismissed from Military Service and Some Other Persons" were appointed regardless of age if they had 20 years of service or more at the date of dismissal from military service, with the exception of persons specified in part three of Article 5 of this Law (paragraph "a" Article 12) [4].

After the reform for the specified category, a gradual increase of service years from 20 to 25 years or more was expected [3]. An increase of service years for five years greatly affects the emergence of the right to a pension payment, and thus reduces the level of guarantees for pension provisions compared with earlier legislation, terminates the retirement for superannuated pensions of citizens dismissed from military service and those equated to them. Despite this, the conditions for the appointment of superannuated pensions were changed, in part of increasing the duration of service years, and 
for other categories of pensioners from the number of military personnel, mentioned in Article 12 of the Law.

It is noteworthy that the overwhelming majority of post-soviet countries retains the right to enter a well-deserved rest for persons dismissed from military service in the presence of 20 years or more of service. Thus, for example, the Law of the Republic of Belarus "On Pension Provision of Military Personnel, Persons of the Commanding and Private Staff of the Internal Affairs, Bodies and Subdivision of Emergency Situations and Financial Investagations" stipulates that the military personnel has the right to pension provision for service years who took military service for contract, persons of the commanding and private staff who have service years in military service and (or) who are in service for 20 years or more [5].

Also there were significant changes for norms of determining the maximum amount of superannuated pensions for persons dismissed from military service in the direction of its reducing. According to Article 13 of the Law of Ukraine "On Pension Provision of Persons Dismissed from Military Service, and Some Other Persons", the maximum amount of pension calculated in accordance with this Article shall not exceed 70 percent of the corresponding amounts of cash provision [3]. The earlier version of the Article stipulated that the maximum amount of pension should not exceed 90 percent of the corresponding amounts of cash provision [4].

In Ukraine, the reform of pension provision for persons dismissed from military service is continuing, and the Ukrainian government considers it through the prism of the word "modernization". In 2018, the Resolution of the Cabinet of Ministers of Ukraine No. 103 "On the Recalculation of Pensions to Persons Dismissed from Military Service, and Some Other Categories of Persons" was adopted, as well as a number of subordinate legal acts, the informative analysis of which gives grounds to assert that the modern state pension policy on persons dismissed from military service is aimed at reducing, firstly, of the number of military pensioners, and secondly, of the level of material security of this category of citizens.

In the context of our study, attention should be paid to the recalculation of previously assigned pensions to persons dismissed from military service and those equated to them. Thus, according to 
part 2 of Article 63 of the Law of Ukraine "On Pension Provision of Persons Dismissed from Military Service, and Some Other Persons" in case of submission by the pensioner of additional documents that give the right to further increase the pension, the pension is transferred according to the provisions of this Law. At the same time, part 4 of the above-mentioned article states that all pensions provided by this Law are to be recalculated in connection with the increase in the monetary provision of the corresponding categories of military personnel, persons entitled to a pension under this Law, on the terms, in the order and in amounts provided by the Cabinet of Ministers of Ukraine [3].

As it's seen, in the first case the legislator indicates that the recalculation of pensions is conducted on the basis of the rules of the Law, in the second - on conditions, in the order and amounts provided by the government. The presence of these contradictions, on the one hand, misleads pensioners from among military staff, complicating enforcement practice and creating another problem of double legislation, on the other hand, leads to ambiguous interpretation and understanding of normative provisions, does not contribute to a comprehensive understanding of the issues of recalculation of previously assigned pensions. The remark needs additional legal regulation and clarification.

At the same time, in practice, the territorial bodies of the Pension Fund recalculate the previously assigned pensions in the manner and under the conditions provided by the Resolution of the Cabinet of Ministers of Ukraine No. 103 "On the Recalculation of Pensions to Persons Dismissed from Military Service, and Some Other Categories of Persons" of February 21, 2018 [6], essentially ignoring part 2 of Article 63 of the Law of Ukraine "On Pension Provision of Persons Dismissed from Military Service, and Some Other Persons".

Conveys comments on "components" that are taken into account when calculating pensions for persons dismissed from military service. Part 1 of Article 63 of the Law of Ukraine "On Pension Provision of Persons Dismissed from Military Service and Some Other Persons" provides that the recalculation of previously assigned pensions to military personnel, persons entitled to a pension under this Law and members of their families in connection with the entry into force of this Law is conducted on documents in the pension case, 
as well as additional documents submitted by pensioners at the time of recalculation [3]. That is, from this normative provision it follows that the recalculation of the previously assigned pension is based on all incomes, the information about which directly is in the pension case or submitted by the pensioner at the time of recalculation.

With the entry into force of the Resolution of the Cabinet of Ministers of Ukraine No. 103 "On the Recalculation of Pensions to Persons Dismissed from Military Service and Some Other Categories of Persons", the recalculation of pensions for persons dismissed from military service and some other persons is conducted taking into account three components of the cash provision determined on March 1, 2018, namely:

- the size of the salary by position;

- military (special) title;

- a percentage bonus for superannuated pensions for the corresponding or similar position occupied by the person on the date of dismissal from service (on the date of the trip for work to the state authorities, local authorities or their formed bodies, enterprises, institutions, organizations, higher educational institutions institutions) [6].

As we see, the components of the recalculation of previously assigned pensions do not include the amounts of monthly additional types of cash provision support (bonuses, surcharges, increases), premiums, rehabilitation benefits, one-time cash aid paid to military personnel in the event of dismissal from military service for health reasons, by their own desire, due to family circumstances or other valid reasons, etc.

It seems especially unfair to conduct a recalculation of pensions for military pensioners who worked and/or work in higher military educational institutions and military training units of higher educational establishments, without taking into account additional payments for academic titles and degrees. In particular, the existence of the outlined situation calls into question the expediency of paying a single contribution to the compulsory state social insurance on the amount of monthly additional types of cash provision.

At the same time, there is a need to revise existing approaches to determining the amount of pension reform. In accordance with paragraph 2 of the Resolution of the Cabinet of Ministers of Ukraine 
No. 103, provision is made for a phased payment of the recalculated pensions, designated in accordance with the Law of Ukraine "On Pension Provision of Persons Dismissed from Military Service, and Some Other Persons" (except for pensions, appointed in accordance with the Law to persons of command and private staff of internal affairs bodies (police), starting from January 1, 2018, in the following sizes:

- from January 1, 2018 - 50 percent;

- from January 1, 2019 to December 31, 2019 - 75 percent;

- from January 1, 2020 - 100 percent of the increase in the pension, as of March 1, 2018 [6].

The presence of these normative provisions does not guarantee the proper amount of the recalculated pension and contribute to the material security of persons dismissed from military service, in particular, we consider it unfair to pay the recalculated pension in full, but in percentage to the amount of increase. In spite of the mentioned, it seems inappropriate and absurd to pay in 2019 and 2020 on the basis of the increase set for 2018, as in modern conditions there is a significant rise in prices for goods and services and inflation. In connection with the mentioned arguments, we consider it expedient to pay the full amount of pensions to the sum of increase, directly determined for the current calendar year.

Other measures of life support for persons dismissed from military service, which are provided for in the Law of Ukraine "On Pension Provision of Persons Dismissed from Military Service, and Some Other Persons", are also noteworthy, in particular regarding the indexation of pensions. The essence of this measure was regulated by Article 64 of the Law, which stipulates that pensions for military personnel, persons entitled to pensions under this Law and members of their families shall be increased in accordance with the Law of Ukraine "On the Indexation of Monetary Income" [3]. At the same time, the generalization of practical experience shows that the indexation of pensions for persons dismissed from military service is not conducted, this measure applies to unemployed pensioners who receive the pensions in the minimum amount, appointed on the general terms. 
Conclusions. Thus, on the basis of the mentioned above, we can state that the reform of the normative-legal regulation of the pension provision of persons dismissed from military service has led to a deterioration in the level of material security, restriction and limiting of pension rights. In addition, there is an urgent need for clarification of the normative-legal regulation of the recalculation of previously assigned pensions, as well as the revision, firstly, of the components of the cash provision from which the pension is recalculated, by including the sums of monthly additional types of cash provision (bonuses, surcharges, increases), premiums, including one-time benefits paid when dismissed from military service; and secondly, approaches to determining the amount of recalculation of the previously assigned pension.

\section{References}

1. Kravchenko M. V., Razumtseva G. I. and Trach V. E. (2017), "Ways to improve the state regulation of the system of social protection of servicemen and their families in Ukraine", Public Administration: Theory and Practice, No № 1, pp. 38-49.

2. Stashkiv B. I. (2018), "The right to social security. Special part: tutorial", Desna, Chernihiv.

3. Verkhovna Rada of Ukraine (1992), "The Law of Ukraine on Pensions of Persons Discharged from the Military Service, and some other persons", in ed. dated August 31, 2018, Verkhovna Rada of Ukraine, Kyiv.

4. Verkhovna Rada of Ukraine (1992), "The Law of Ukraine on Pensions of Persons Discharged from the Military Service, and some other persons", in ed. dated January 1, 2011, Verkhovna Rada of Ukraine, Kyiv.

5. Verkhovna Rada of the Republic of Belarus (1992), "Law of the Republic of Belarus On the pension provision of servicemen, officers of the command and staff of the bodies of internal affairs, bodies and subdivisions of emergency situations and bodies of financial investigations", Verkhovna Rada of the Republic of Belarus, Minsk.

6. Cabinet of Ministers of Ukraine (2018), "The Resolution on the Recalculation of Pensions to Persons Discharged from Military Service and some Other Categories of Persons", Cabinet of Ministers of Ukraine, Kyiv. 
Денисенко К. В., кандидат наук з державного управління, доцент кафедри теорії та історії держави і права, конституційного права, Академія Державної пенітенціарної служби, м. Чернігів, Україна

\section{ПЕНСІЙНЕ ЗАБЕЗПЕЧЕННЯ ОСІБ, ЗВІЛЬНЕНИХ З ВІЙСЬКОВОЇ СЛУЖБИ: ПРОБЛЕМНІ ПИТАННЯ ТА ПЕРСПЕКТИВИ ВДОСКОНАЛЕННЯ}

У статті здійснено узагальнення нормативно-правового регулювання пенсійного забезпечення осіб, звільнених з військової служби та прирівняних до них осіб. Виокремлено проблемні питання щчодо призначення, перерахунку та виплати пенсій особам, звільненим з військової служби в контексті реформування пенсійного законодавства на сучасному етапі державотворення та вироблено конкретні иляхи вдосконалення зазначеної сфери. Обтрунтовано, щио реформування пенсійного забезпечення щзодо колишніх військовослужбовців приводить до звуження та обмеження пенсійних прав.

Ключові слова: пенсійне забезпечення, пенсійна система, особи, звільнені з військової служби, нормативно-правове регулювання, пенсіонери, пенсійна реформа, перерахунок пенсій. 